\title{
Mademoiselle Bonafon and the Private Life of Louis XV: Communication Circuits in Eighteenth-Century France
}

\section{Citation}

Darnton, Robert. 2004. Mademoiselle Bonafon and the private life of Louis XV: Communication circuits in eighteenth-century France. Representations 87(1): 102-124.

\section{Published Version}

http://dx.doi.org/10.1525/rep.2004.87.1.102

\section{Permanent link}

http://nrs.harvard.edu/urn-3:HUL.InstRepos:3403049

\section{Terms of Use}

This article was downloaded from Harvard University's DASH repository, and is made available under the terms and conditions applicable to Other Posted Material, as set forth at http:// nrs.harvard.edu/urn-3:HUL.InstRepos:dash.current.terms-of-use\#LAA

\section{Share Your Story}

The Harvard community has made this article openly available. Please share how this access benefits you. Submit a story.

Accessibility 


\title{
Mademoiselle Bonafon and the Private Life of Louis XV: Communication Circuits in Eighteenth-Century France
}

\author{
The Older Rhymes in Mother Goose... \\ Hark! Hark! the dogs do bark. \\ The beggars are coming to town. \\ Old chairs to mend! Old chairs to mend! \\ I never would cry old chairs to mend \\ If I'd as much money as I could spend. \\ Christmas is coming, the geese are getting fat. \\ Please to put a penny in an old man's hat.
}

. . confirm a well-known characteristic of early modern cities: they were noisy. ${ }^{1}$ Beggars, peddlers, hawkers, bawlers, mongers, mountebanks, knife sharpeners, hurdy-gurdy grinders, recruiting sergeants, porters, stevedores, wagon drivers, coachmen, endless varieties of laborers and animals filled the air with a cacophony unlike anything heard in the streets today. Through it all ran a stream of sound that is particularly difficult to detect at a distance of two or three centuries: "public noises" (bruits publics) or loose talk about affairs of state and the grandees who directed them. This rumor-mongering belonged to an oral system of communication that provided cities with their basic supply of news. Like most oral phenomena, it has disappeared. But it left traces of its activity at nodal points where the spoken word was picked up by writing and, in some cases, diffused still further by print. Talking and writing, hearing and reading, ran together and amplified each other in ways that spread information everywhere, although they have rarely been noticed by historians. ${ }^{2}$ The difficulty in studying this subject comes from a lack of documentation. With some luck, however, a researcher will come across a dossier

\footnotetext{
A BSTRACT In 1745 a chambermaid in Versailles was shut up in the Bastille for publishing a roman à clef about the sex life of Louis XV. In attempting to get to the bottom of the case, the police uncovered some remarkable information about how oral media and print culture intersected. Their investigation opens up some broad issues related to the history of women, authorship, reading, and public opinion. / REPRESENTAT I O NS 87. Summer 2004 (C) The Regents of the University of California. I SSN 0734-6018, electronic Is s 1533-855X, pages 102-24. All rights reserved. Direct requests for permission to photocopy or reproduce article content to the University of California Press at www.ucpress.edu/journals/rights.htm.
} 
that shows how circuits intersected, blending oral and printed versions of events. Conditions probably were similar everywhere in Europe under the anciens régimes, but the richest source of case studies is the archives of the Bastille, which reveal communication systems at work in eighteenth-century Paris.

If I may take up the investigation at the point where I left it in a study of the circulation of books, I would like to cite a retrospective best-seller list of the forbidden works that were most in demand during the twenty years before the Revolution:

L'An $2440 \ldots$ by L. S. Mercier

*Anecdotes sur Mme la comtesse Du Barry by M. F. Pidansat de Mairobert

Système de la nature by P. H. baron d'Holbach

Tableau de Paris by L. S. Mercier

Histoire philosophique . . by abbé G. T. F. Raynal

* Journal historique de la révolution opérée ... par M. de Maupeou . . . by M. F. Pidansat de Mairobert and B. F.J. Moufle d'Angerville

L'Arrétin by H.J. Du Laurens

Lettre philosophique par $M$. de $V^{* * * *}$, anonymous (not to be confused with Voltaire's Lettres philosophiques)

* Mémoires de l'abbé Terray ... by J.-B. L. Coquereau

La Pucelle d'Orléans by Voltaire

Questions sur l'Encyclopédie by Voltaire

*Mémoires de Louis $X V$, anonymous

* L'Espion anglais ... by M. F. Pidansat de Mairobert

La Fille de joie, a translation of Fanny Hill, possibly by C.-L. Fougeret de Monbron

Thérèse philosophe, probably by J.-B. de Boyer, marquis d'Argens ${ }^{3}$

Admittedly, this list concerns only the illegal sector of the book trade. But owing to censorship and the monopolistic practices of the booksellers' guild, illegal literature represented a large proportion of overall book sales. The French had developed a healthy appetite for the taboo, and the list shows which books made up the greatest part of their diet. Five of the fifteen top best-sellers, those whose titles are preceded by an asterisk, were libelles or chroniques scandaleuses - that is, they belonged to a variety of muckraking and mudslinging journalism, which built up an account of contemporary history by tearing down the reputation of public figures, beginning with the king. I find this result revealing, but others might shrug their shoulders and dismiss it by observing that there has always been plenty of muck to rake in history: why attribute so much importance to the deluge that hit Louis XV, his mistresses, and his ministers? In other words, so what?

The "so what" objection is one of the hardest for historians to answer. I would like to leave it hanging for a while in order to present a dossier from the archives of the Bastille, one in which it is possible to study connections between printed and oral modes of communication, or books and talk. ${ }^{4}$

In August 1745, the police discovered that a particularly objectionable book about the king's love life, thinly disguised as a fairy tale under the title Tanastès, was 
circulating under the cloak. They picked up a peddler, who told them that he had drawn his stock from a secret entrepot in Versailles kept by a bookseller named Dubuisson. Dubuisson was promptly whisked off to the Bastille and interrogated. He had got the manuscript, he said, from a certain Mazelin, a valet of the subgoverness of the dauphin; Mazelin had got it from its author, Marie-Madeleine Bonafon, a chambermaid to the princesse de Montaubon; and she had parted with it in return for two hundred copies of the edition that Dubuisson had arranged to have printed in Rouen, in the shop of the widow Ferrand.

One detachment of police went back to Versailles for Mazelin and Mlle Bonafon; another set off for Ferrand's shop in Rouen; and meanwhile the inspectors continued to haul in peddlers from the streets in Paris. In the end, they filled the Bastille with twenty-one voluble prisoners, whose interrogations reveal a great deal about underground publishing. The most revealing testimony came from the author, Mlle Bonafon. On August 29, after spending two nights alone in a cell, she was led before Claude Henri Feydeau de Marville, the lieutenant general of police.

The lieutenant general was one of France's top officials, roughly the equivalent of the minister of the interior today. He did not personally interrogate prisoners in the Bastille, except in important affairs of state. In this case, he evidently smelled something suspicious, because chambermaids did not write political novels, even though some of them had received good educations. (The best known today is Jeanne Louise Henriette Campan, the highly literate femme de chambre of MarieAntoinette.) Was someone hiding behind Mlle Bonafon, someone familiar with the corridors of power and who might have furnished her with a draft of the political story that she had reworked as a fairy tale? Conspiracies were simmering in the court at this time. Mlle Bonafon's patron, the princesse de Montauban, was linked with the so-called devout party (parti dévot), which felt itself threatened by the growing power of the duc de Richelieu and the king's mistresses. The latest mistress, Mme de Pompadour, was about to be presented at court, and she was becoming aligned with the comte d'Argenson, minister of war, at the expense of his rival, the comte de Maurepas, a dangerous master of political intrigue who was minister of the navy and of the king's houschold. Marville himself reported to Maurepas but aspired to become a protégé of Pompadour. Whatever plot might be brewing, he needed to get to the bottom of it. He also needed to prevent the inner workings of Versailles from being exposed before the public. Reputations could be damaged if gossip became transformed into print, and reputation was the stuff of power struggles at court. Marville therefore prepared the interrogation carefully and conducted it like a cat-and-mouse game. He laid traps; Mlle Bonafon tried to avoid them; and the transcript of the interrogation recorded all their moves, for it was written in the form of a dialogue: question-answer, question-answer, each page initialed by Mlle Bonafon as testimony to its accuracy. ${ }^{5}$

Marville got through the preliminaries quickly: Mlle Bonafon took an oath to tell the truth and identified herself as a native of Versailles, twenty-eight years old, 
employed for the last five years as chambermaid to the princesse de Mountauban. Then he came immediately to the point: Had she written any books?

Yes, she said: Tanastès, and the beginning of another one, Le Baron de xxx , and also a play, which had never been performed and was now in the keeping of the son of Minet of the Comédie française. (She later said that she had also completed the drafts of two other plays, Les Dons and Le Demi-Savant, and had composed a good deal of poetry.)

Asked what it was that gave her a taste for writing? Hadn't she consulted someone who was familiar with the composition of books in order to learn how to go about organizing the ones she intended to write?

Answered that she did not consult anyone; that since she reads a great deal, this had given her a desire to write; that she had imagined, moreover, that she could make a little money by writing; that no one had taught her the rules of the theatre but that she had learned them herself by reading plays; that she had in fact consulted Minet a few times for her play, Le Destin, but as to the other novel she had mentioned, she had worked on it all by herself; that she had never spoken about Tanastès to anyone except sieur Mazelin so that he could find someone who would take charge of getting it printed for her.

It was an extraordinary moment: a female servant telling the head of the police force, one of the most powerful men in the kingdom, that she had written a novel because she wanted to write a novel and that she had done it on her own, without help from anyone. The lieutenant general could not take it in.

"Had she written the book out of her own imagination?" he asked. "Hadn't someone supplied her with written material to work over? Who was it that had given [that material] to her?"

Replied that no memoirs had been given to her, that she had composed her book by herself, that in fact she had fashioned it in her imagination. Agreed, however, that having her head full of what people were saying in public about what had happened during and after the king's illness, she had tried to make some use of it in her book, but without understanding the consequences and without having the slightest evil intention; and added that the more she sensed her wrong, the more she felt penetrated with unhappiness.

Marville did not stop at these general disclaimers. He demanded precise information about the production and diffusion of the book. (Here I will paraphrase the interrogation, keeping close to the wording in the transcript.)

When had she written it?

In December-January and in March, 1745.

What were the arrangements for its publication?

Mazelin had delivered the manuscript to Dubuisson, who had promised to give her two hundred copies in exchange for it. Dubuisson or someone in his employ must have provided the Latin epigraph, the preface, and the notes, which were not her work.

Where was it printed?

In Rouen, according to Mazelin. 
What had she done with her two hundred copies?

She had burned them.

When?

After she heard that the police had arrested Dubuisson.

At this point, the questioning entered into dangerous territory, because it began to cut into Bonafon's defense. Although she could not deny her authorship of $T a$ nastès (she had already confessed to her mistress, the princesse de Montauban), she attempted to represent the book as an innocent romance vaguely inspired by the common gossip of the court. Meanwhile, Marville tried to lure her into admitting that she had known all along that it was a scandalous attack on the king. The fact that she had waited until the last minute to destroy her copies demonstrated her intention to profit from the scandal that she had knowingly exploited. So while Bonafon withdrew behind her version of the affair, Marville circled round it, aiming questions at its weak points.

Didn't Mazelin warn her, when he first read the manuscript, that it could lend itself to "mauvaises applications" or dangerous parallels with current affairs?

Yes, but she had assured Mazelin that it was merely a story and that many such stories appeared every day without giving rise to "applications."

If Mazelin had warned her of the danger, why did she persist in getting the book published?

She had been wrong, she admitted, but she did not see anything sinister in the "applications." She went ahead with the publication only because "she was so hard pressed for money."

Wasn't there a key to the story? Wasn't one joined to the copies she had received?

No: she had seen a key three weeks ago, a manuscript attached to some copies on sale in Dubuisson's stall in Versailles, but she had nothing to do with it.

That remark exposed a weak flank in Mlle Bonafon's defense, and Marville immediately attacked.

So! Long before she had burned her copies, she knew all about the "applications"; yet she had persisted in her plans to sell the book. Indeed, she would have sold off her entire stock had Dubuisson not been arrested. She was guilty of manufacturing and diffusing "the most indecent work in the world"! Wasn't she herself the author of the key? Or was it Mazelin? The precautions they took to camouflage their operation proved that they knew how wicked it was.

Not at all, she replied. She had resorted to secrecy only because she did not want to be known as an author. It was her desperate need for money that had compelled her to publish the book; and she certainly had not written the key, nor did she believe that Mazelin had supplied it.

Marville broke off the interrogation at this point. He had extracted enough information to prove Mlle Bonafon's complicity in a criminal variety of literature, 
but he suspected there was more to the story than she would admit; for what business did a servant, a female domestic servant, have to do with the writing of novels? To get to the story behind the story, he would have to interrogate the other prisoners in the Bastille; and he had quite a collection of them.

Eventually the lieutenant general and his assistants worked their way through all twenty-one cases, imprisoning some of the suspects, exiling others, and freeing the occasional peddler and printer's devil. They acquired a complete knowledge of the underground network linking Rouen, Versailles, and Paris. But their main concern remained the mystery of authorship — of the key as well as the novel一-so they concentrated on Mlle Bonafon. They called her back for two more interrogations, continuing to lay traps that she continued to avoid. But they made more progress with her collaborators. When they extracted some compromising information from one suspect, they cross-examined another, holding the information back until they caught him in a lie. Then they hit him with his accomplice's testimony in an attempt to provoke a confession. They also tried to break through the prisoners' defenses by a technique known as "confrontation." They summoned Mlle Bonafon and Mazelin from their separate cells and then read the testimony of each to the other, trying to touch off mutual recriminations. When this got them nowhere, they summoned Dubuisson and did the same. His story about the key to the novel flatly contradicted theirs, but no one would back down; so the investigation remained stalled for several days, until at last the interrogators got Maillard, the concièrge of the marquis de Prye, to break down. He admitted that he had operated a secret entrepot in the marquis's town house in Paris. He had supplied the Parisian peddlers, and he had drawn his own stock from Versailles: forty-five copies came from Mazelin and twenty-five from Mlle Bonafon, who was to receive three livres tournois for every copy sold. The package sent by Bonafon included the key, written out in her hand.

Maillard's confession armed the lieutenant general with the information he needed in his third interrogation of Mlle Bonafon. He kept it concealed at first, while he asked the usual questions about the key and got the usual denials. Then he pounced.

Did Mlle Bonafon know a certain Maillard, concièrge of the marquis de Prye?

She had seen him once with Mme de Prye in Versailles.

Had she ever written to Maillard or transmitted copies of Tanastès to him?

No.

She was lying. He knew full well that she had sent twenty-five copies to Maillard and had been involved in a shipment of forty-five others, hoping to collect three livres from each sale.

At this point, the last bulwark in Mlle Bonafon's defense collapsed, and she had no recourse but to confess, keeping back as much information as she could.

Yes, she admitted, it was true: she had tried to make some money from the copies that had remained at her disposal. She had confided them to a servant of 
the prince de Constantin, who had taken them past the customs without difficulty in the prince's carriage.

Had she sent a key in the package?

Yes, she could not deny it. Maillard needed the key to sell the book; so she wrote it out in her own hand and gave it to Mazelin for Maillard-but with the proviso that it was for Maillard's information only and not to be distributed with the books. Marville then produced a piece of paper covered with handwriting.

Was this the key?

Yes, she confessed; it was the very copy that she had sent to Maillard, in her own hand. All she could say in defense of herself was that she never made any money from the book.

Brushing this excuse aside, Marville delivered a lecture.

"Brought it to her attention that since her detention she has developed a system of admitting to some of the facts held against her and denying the others." She was guilty of producing and distributing the most disrespectful and dangerous kind of literature. She had tried to enrich herself by slandering the crown. And she could expect to stay in prison until it pleased the crown to accord her grace.

In fact, Mlle Bonafon remained in the Bastille for fourteen and a half months. Her health deteriorated so badly that, according to a report from the Bastille's governor, she seemed likely to die unless she were transferred to a healthier site. She was therefore shut up in the convent of the Bernardines at Moulins, where she remained, without permission to receive either visitors or letters, for the next twelve years.

I recount this little scene from the Bastille because it dramatizes one of the major concerns of the police: the control of public opinion. True, they did not use the word, but they worricd about the thing - that is, the way Parisians talked about men in power and affairs of state. When the talk metamorphosed into a book, which was sold throughout the kingdom, the affair became serious enough for the lieutenant general himself to take charge of the investigation. It is the connection between talk and print-Bonafon's insistence that she had published an imaginative version "of what people were saying in public about what had happened during and after the king's illness"- that seems especially revealing to me.

Consider the analysis of public opinion developed by Gabriel Tarde, a nineteenth-century sociologist best known, if he is remembered at all, as an opponent of Emile Durkheim. ${ }^{6}$ Tarde argued that public opinion emerged from the mutual reinforcement of two phenomena, print and conversation. The printed word, first in the form of books, then as the daily newspaper, provided a "menu" for conversations, and the talk coalesced in collective judgments, which later found their way back into print as expressions of the public's views. At an early stage in this process, when the book remained the dominant medium among educated Frenchmen, readers tended to be isolated and conversations scattered thinly 
through polite society. The advent of the cheap daily newspaper and mass literacy transformed the nature both of reading and of the news. While perusing the paper in nineteenth-century Paris, readers became conscious of taking in the same version of the same events at the same time as everyone else- not at the breakfast table, because home-delivery began much later, but rather in the cafe and the tavern, where people read papers and discussed politics at the same time. Even isolated readers participated in this collective undertaking, because in passing judgment on the news-approving or deploring a speech, a military maneuver, or even the weather - they were aware of reacting simultaneously with others. Whether or not they engaged in direct debate, all readers shared a sense of immersion in the flow of information and of participation in the general process of assimilating and assessing news. The more vocal reactions fed into the news of the next day; so the process reinforced itself. Opinions divided, reports disagreed; but at its heart, the reading-conversing dialectic produced a common consciousness, l'esprit public, or public opinion.

As Elihu Katz, a modern sociologist, has argued, Tarde's theory can be used to reinvigorate the tradition of communication research developed by Paul Lazarsfeld, Robert Merton, and Harold Lasswell. ${ }^{7}$ It may open a way to a better understanding of modern media, such as television and the internet; but it cannot be applied so easily to eighteenth-century France, because the journalism of the 1740s was primitive in comparison with that of the 1840s. France did not have a daily newspaper until 1777. The weekly Gazette de France contained little more than official proclamations and announcements of ceremonies at court. More news, especially about foreign relations, could be found in French journals published outside France. But the most important of them, the Gazette d'Amsterdam and the Gazette d'Utrecht, which could be had once or twice a week inside the kingdom, contained only short and circumspect articles about domestic affairs and revealed nothing about actual struggles for power. ${ }^{8}$

For example, here is the account of the most important political event of 1749, the fall of the Maurepas ministry, in the Gazette d'Amsterdam. It appeared twelve days after the fact and took up one sentence:

Paris, April 24. Toward 9:00 in the morning, the comte d'Argenson, Minister and Secretary of State in the War Department, went, at the King's order, to the residence of the comte de Maurepas and handed him a lettre de cachet by which His Majesty ordered him to retire to Bourges. ${ }^{9}$

The same report, nearly word for word, appeared in the Gazette d'Utrecht eight days after it took place and in the Gazette de France twelve days after its occurrence. ${ }^{10}$ The fall of Maurepas involved a crucial shift in the balance of power at Versailles, but the Parisians would never know so by reading the legal press.

Could they inform themselves from illegal manuscript newsletters or nouvelles à la main such as the famous underground journal produced in the salon of Mme 
M.-A. L. Doublet? ${ }^{11}$ The salon resembled an amateur newsroom. It contained two registers prepared by Doublet's servants, one with reliable reports of the day's news and one with unsubstantiated gossip. When the salon members arrived, they read through both registers, added whatever news they had picked up themselves, and then gathered over a meal to discuss it all. They fit Tarde's formula exactly: the news provided a menu for talk, and a revised version of it, filtered through conversation, circulated everywhere in manuscript copies. One of those copies for 1749 survives in the Bibliothèque nationale de France, and it contains a report on Maurepas's fall. But what a disappointment! It is nearly the same as the one-sentence account in the Gazette d'Amsterdam: "At 9:00 this morning M. d'Argenson brought a letter from the king to $M$. de Maurepas by which His Majesty removed him from his offices and ordered him to go to Bourges." 12 Evidently it was made from the first register, the one that contained only summary versions of "hard" news. All the other entries for the 1740s are equally anodyne-not surprisingly, because the police kept a close watch on the Doublet salon and could have cracked down on it, if it circulated information that the government wanted to suppress. The clandestine newsletters provided little more than the foreign gazettes for Parisians hungry to learn about the struggle for power in 1749.

But there was no denying the demand for such information. Later versions of Mme Doublet's newsletter, printed after 1777 (but covering the period from 1762) as Mémoires secrets pour servir à l'histoire de la république des lettres en France, contain full accounts of political in-fighting and intrigues among the great. They probably were published from copies of the second register, the one crammed with gossip. Gossip flowed freely in the wake of the gazettes, but where did it come from? Not normally from the gazettes themselves, at least not before 1750, when few underground journals dared to discuss the private lives of public figures and few readers had access to them. Yet the police records demonstrate that ordinary Parisians regaled themselves every day with talk about the inner workings of Versailles. If we try to apply Tarde's formula to the early eighteenth century, we therefore face a problem: Where, if not from newspapers, did Parisians find a menu for the day's talk?

Perhaps none existed. But I suspect it was there, not printed, not in writing, not even seen, but heard, floating in the air, in the form known as "public noises" (bruits publics) under the Old Regime. It belonged to an oral communication system peculiar to early modern cities, one that Louis Sébastien Mercier described in 1786 as a "murmur, which one continually hears in Paris."13 Unfortunately, most of the murmuring disappeared into the air. But some of it left traces in the archives of the Bastille, because the police often arrested people for "bad talk" (mauvais propos, mauvais discours) in public places. The arrests increased significantly in the late 1740s. Here are some typical cases, as summarized in notes by a clerk in the Bastille, from the spring of 1749 : 
16 April: the chevalier de Bellerives, former captain of dragoons, for discours against the king, Mme de Pompadour, and the ministers.

9 May: The sieur Le Clerc for mauvais propos against the government and the ministers.

10 May: François-Philippe Michel Saint Hilaire for mauvais propos against the government and the ministers.

10 May: The sieur Le Brest for mauvais propos against the government and ministers.

3 June: the sieur de Chassan for mauvais propos against the government. ${ }^{14}$

Of course, prison archives have a built-in bias: they concern persons deemed to be criminal; so they can give the misleading impression that everyone was badmouthing the government. But the police also compiled reports on what ordinary people said in cafes, public gardens, and market places. A network of spies-perhaps as many as three thousand - provided the information, and primitive journalists, like the notorious chevalier de Mouhy, wrote it up in bulletins furnished every day to the lieutenant general, who then adapted it for presentation to the minister for the department of Paris and, eventually, the king. In short, the police produced a gazette of their own. Copies were leaked, for a price, to important grandees, like the maréchal de Saxe, one of Mouhy's clandestine customers. And several copies survive, though only in fragments, in various archives; so we can begin to put together an account of the public noises picked up by the police. It is a tricky business, because the police gazeteers filtered their information and wrote it up in ways that would ingratiate themselves with their superiors. One cannot read them literally. But, however biased, they provide accounts of the tone, the place, and the participants of the talk - that is, they contain information about information.

Here is a report by Mouhy himself on cafe conversations at the height of the War of the Austrian Succession (1740-1748):

Businessmen, retired officers, the common people are all complaining, speaking ill of the government and predicting that this war will have disastrous consequences. Clergymen, especially the Jansenists, take that view and dare to think and to say aloud that the evils that will soon overwhelm the kingdom come from above, as punishment for the incest and irreligion of the king. They cite passages from Scripture and make analogies ["font des applications".] The government should pay attention to this class of subjects. They are dangerous. ${ }^{15}$

The notion of "applications" brings us back to Mlle Bonafon. The hostile remarks picked up by Mouhy were the kind that she incorporated into her book. In a report on Tanastès, the police described it as "a work that provides a journal [un récit où l'on faisait le journal] of what happened at Metz during the king's illness and of the reestablishment of Mme de Chateauroux." 16 To provide a journal in the case of Mlle Bonafon was to tell a story that ordinary journals could not print. Instead of reporting events as news, she dressed them up as a fairy tale. She took her 
material from the gossip of Versailles and reworked it as a thinly disguised chronique scandaleuse. The implicit "applications" that run through the narrative compelled the readers to construe it in a certain way, as the police themselves indicated in their report to the government. They summarized their own reading of the text as follows:

This book is an allegorical fairy story, from which it is easy to make offensive applications [applications injurieuses] to the king, the queen, Mme de Chateauroux, the duc de Richelieu, the cardinal de Fleury and other grandees and ladies of the court. It gives an account of what happened during the king's sickness at Metz in 1744; the renunciation of Mme de Châteauroux; her return to favor and her reestablishment; her illness, her death, and the new choice of Mme de Pompadour. ${ }^{17}$

The police obviously had an eye for literature under the Old Regime. But why did they become so exercised over a fairy tale, even one with "applications"? Why did this political romance, penned by a chambermaid, turn into an affair of state, something handled at the highest level-for, as the police also noted, it "had, with reason, greatly displeased the king." 18 Veiled accounts of the royal love life had appeared in print for at least a century before 1745. The best-known example of the genre, Histoire amoureuse des Gaules by Bussy-Rabutin, cast Louis XIV as "le grand Alcandre," the supreme gallant in a world of gallantry, and it did not displease the king until Bussy's enemies reworked it in a defamatory vein as La France galante, which eventually stretched to five volumes.

Tanastès looks thin in comparison, but it deserves study, despite its clumsy plot, which makes it seem excessively contrived to the modern reader. Here is an attempt at a summary: A prince (Tanastès, or Louis XV according to the key) is born in the land of the Zarimois (the French). A sylph snatches the baby and consigns it to a tutor (Oromal, the cardinal de Fleury), who is to instruct him until he is ready to assume the throne. Meanwhile, an evil look-alike (Agamil) is substituted for the prince. He gives free rein to his lust, as he grows up, while Tanastès observes him indignantly from a cloud. First Agamil takes up with "an antique fairy" (Mme de Mailly, Louis XV's first mistress among the daughters of the marquis de Nesle), who is good-natured enough to minimize the damage to the kingdom. But then he turns her in for a better-looking mistress (Mme de Lauragais, daughter number two), and finally settles on a passionate, scheming femme fatale, "Ardentine" (Mme de Châteauroux, daughter three), who makes him her slave and rules "despotically" over the kingdom. When a war breaks out, Agamil goes off to fight at the front, and Ardentine follows him. On her way, she encounters the good king, Tanastès, whom she takes to be Agamil; but when she makes advances to him, he rejects her. In a fit of spite, she returns to the court and, with the help of a magic wand, banishes everyone to a hellish underground kingdom of gnomes. At this moment, the climax of the story, the supreme sylph (Amariel, the bishop of Soissons) intervenes. He arms Tanastès with some magic lightning and sends him to rescue the court. Ta- 
nastès routs the gnomes (actually he turns out to be rather weak-kneed in the crunch, but the lightning does the job); the bad king is transformed into a snake; the wicked mistress swallows the snake; as it gnaws at her entrails, she is banished to the underground; the good king is reunited with the queen (thanks to some bedroom magic by the sylphs, they had been spending the nights together and the days apart); and they are ready to rule happily ever after ... or at least to part two. ${ }^{19}$

I won't attempt to summarize the twists and turns of part two, but I should explain that, according to Mlle Bonafon's interrogation, it was written later; and it carried the story from the fall of one evil mistress, Mme de Châteauroux, which it recounted once again, to the rise of another, Mme de Pompadour. The two-king, Jekyll-Hyde motif disappeared, or rather became internalized in the figure of Tanastès, who was tricked into drinking a poisonous magic potion composed of the ground-up remains of the bad-king-snake and who therefore became prey to limitless concupiscence compounded by melancholy and ennui. Meanwhile, the queen gave way to religious bigotry. Fearing damnation, she refused to have sexual relations with the king and fell under the spell of priests, who exploited her religiosity in order to increase their own power. Hungering for sex, the king at last found "une grâce" (Pompadour) at a masked ball held to celebrate the marriage of the Dauphin. Pompadour had only recently emerged as the king's mistress when the book was published. So the story ended on an uncertain note. No one could predict how the reign would develop, because the king had now become an ordinary mortal, a mixture of good and evil, part Tanastès and part Agamil.

Not a great yarn, you might say. Why did it cause such consternation among the authorities? Aside from the need to unravel any political intrigues that might lie behind the publication, they confronted a danger that extended far beyond the confines of Versailles: the prospect that the book might convey a hostile reading of current events to ordinary, educated Frenchmen - the same reading, in fact, that the police had made themselves and that could not be avoided, owing to the "applications" woven into the plot. The danger posed by Tanastès derived from its quality as a roman à clef.

Unlike normal novels, which can indeed be appropriated in contradictory ways, romans à clef compel standard reactions on the part of their readers. They operate like puzzles. Venture a page or two into the narrative and you cannot resist making guesses about the public personages hidden behind the fictional characters. Some of the identifications are easy, but some are brain-teasers; and the more complicated the plot-however absurd or hackneyed it may be - the more fascinating is the guessing game. Before long, you find yourself taking notes or writing guesses in the margin or thumbing to the end to find a key-and then correcting it, if it fails to correspond to details in the story. You may go on to formulate reflections of your own, which could be idiosyncratic and independent of what the author may have intended. But whatever you ultimately make of a roman à clef, you cannot get through its text without first decoding it in the way that it requires. And if you lived 
in eighteenth-century France, you would be especially inclined to play that kind of game, because you would have learned to look for "applications" in the works of La Fontaine, La Bruyère, and other best-known authors from the seventeenth century. You would be familiar with similar puzzles - bouts rimés and énigmes-from the pages of literary reviews and from games played at social gatherings. It would be perfectly natural for you to approach reading as puzzle solving.

The copy of Tanastès in the Bibliothèque de l'Arsenal has a manuscript key bound in it at the end. Another key, handwritten on a separate sheet of paper, can be found in a contemporary collection of keys to novels, which is also at the Arsenal. ${ }^{20}$ It is therefore possible for you to puzzle your way through the book as an eighteenth-century reader would have done, making guesses and checking them against the keys every time you encounter a new name or an unexpected turn in the story. Although most of the identifications are obvious, given an adequate knowledge of eighteenth-century history, some are tantalizingly ambiguous. For example, a note printed at the bottom of page 8 in the text identifies the "antique fairy" as the queen; but one of the keys disagrees: "Antique fairy. The note on page 8 of the first part indicates the queen. It should be Mme de Mailly."21 In fact, both interpretations fit the story, but the second is spicier, because it evokes gossip about the king's poor taste in mistresses and his doglike inability to shake off Mme de Mailly in order to trade up to someone prettier.

The guessing game becomes more dramatic as the narrative leads into the secret chambers of Versailles, an area that had not yet been penetrated by print during the reign of Louis XV. Every episode of the plot runs parallel to current events. The king really did take the de Nesle sisters as his mistresses, one after the other, beginning with Mme de Mailly in 1733 (hence the gossip about incest, since sexual relations with sisters was commonly believed to be incestuous); and the turning point in his reign came when he fell ill at the front in Metz, where Mme de Châteauroux had followed him in 1744. At that point, the bishop of Soissons intervened spectacularly, just like Amariel in the fairy tale. He forced the king, who was in terror of dying, to renounce Mme de Châteauroux in order to have access to absolution and the sacrament of extreme unction. Then, while his mistress traveled back to Paris under a hail of insults, the king recovered. The French rejoiced, taking the miracle as a sign that a new Louis, the "Bien-Aimé" (Much Beloved) had emerged in place of the old reprobate. But the Agamil in him returned. Having fallen under the influence of the duc de Richelieu (Muscadin) he called Mme de Châteauroux back to Versailles, and she exploited her return to favor in order to win a dominant position at court, exactly as Ardentine did in part two of the novel. But before she could resume power, she took ill and died-from poisoning, it was rumored. The next chapter of the power struggle, both in the book and in the politics at court, began when Louis picked out the future Mme de Pompadour at a masked ball to celebrate the dauphin's wedding. Before long, she was selecting his ministers. So the private life of the king really did determine the course of events for the kingdom: 
that was the secret revealed by Mlle Bonafon and the source of the excitement conveyed in her fairy tale. ${ }^{22}$

If this account seems hopelessly infected with the trivialities that the French deprecate as petite histoire, it should be remembered that when Tanastès appeared in 1745 no other version of the king's loves and current events was available in print. Mlle Bonafon transformed disconnected items of gossip into a coherent narrative; and after her version of events was peddled in the streets of Paris, it reentered the stream of gossip by creating more "public noise." The oral nature of her sources shows through the text itself as well as her interrogation. For example, in recounting the cessation of sexual relations between the king and queen - the queen, worried about a miscarriage but too embarrassed to admit it, had refused to receive the king in bed-she described how the word spread among the courtiers who had learned of Louis's displeasure at his lever: "They gradually withdrew in order to spread the news of the day. In less than an hour the entire palace was informed of Tanastès's unhappiness. It was the first item in every conversation." ${ }^{23}$ Instead of displacing rumor by reading, the publication of Tanastès amplified the power of word of mouth. Mlle Bonafon acknowledged this effect in her interrogation when she referred to "the great rumor [grand bruit] produced by the book." From talk to print to talk, the media reinforced each other in the eighteenth century much as they did a hundred years later, according to Gabriel Tarde. Mlle Bonafon may not have been a great writer, but she occupied a critical position where oral and written versions of events converged. From this point onward, the process gained momentum. "Mauvais propos" and books poured out, carrying a negative account of the monarchy to increasingly broad sectors of the public. It was the famous deluge, which began in the middle of Louis XV's reign, not afterward, and it had a crucial effect on the contemporary view of contemporary history.

I can hardly do justice to this theme in one essay, but in order to put the Tanastès affair in perspective, I would like to discuss three other novels that followed in its wake. All three were also romans à clef, and all have disappeared into the unstudied substratum of literary history. But taken together, they contributed powerfully to the formation of the mythological view of the reign of Louis $\mathrm{XV}$ as a time of decadence and despotism.

The first novel, Mémoires secrets pour servir à l'histoire de Perse, appeared in 1745 at about the same time as Tanastès and was perhaps even more important, because it provided the narrative frame around which much contemporary history was constructed. Its author was probably Antoine Pecquet, a top official in the ministry of foreign affairs under the comte de Morville, but he seems to have relied on collaborators from the circle of another strong-minded woman, Mme de Vieux-Maisons. ${ }^{24}$ Unlike Mlle Bonafon, she was wealthy and well connected, especially in the milieu of antigovernment agitators in the Parlement of Paris. She looked very suspicious to the police, who put her down in their files as follows: 
Small, very white, blond, with a perfidious physiognomy. She is the wife of a counselor in the Parlement, the sister of Mme de Vauvray, and the daughter of M. Ath, fermier général [a powerful financier and tax collector]. She is very clever and being [also] very wicked, she writes poems and couplets against everyone.... [Her] circle ... is the most dangerous in Paris and is strongly suspected of having produced the Anecdotes de Perse. ${ }^{25}$

The Anecdotes or Mémoires secrets pour servir à l'histoire de Perse (the title varies from edition to edition, and the text went through at least six editions by 1769) contain plenty of gossip, but they incorporate it in a serious history of France from 1715 to 1745, with emphasis on the last five years - that is, the period of the War of the Austrian Succession, which they recount in detail, right up to the present, or the spring campaign of 1745 . The story takes place ostensibly in Asia, and it opens with a vast description, 164 pages in the edition of 1759 , of all the powers involved in the struggle to dominate the continent. The reader must therefore begin the guessing game by filling in a geographical puzzle. Asia is obviously Europe; Persia is France; and Japan, England. But China? (Answer: Spain.) Korea? (Portugal.) Kabul? (Hanover.) Lahore? (Saxony.) Jodhpur? (Prague.) The analogies must have tried the wit of the cleverest readers. (For an example of how they worked, see the appendix at the end of this essay.) When institutions, military capacities, and foreign policies are added to the picture, the puzzle turns into a history lesson. And by completing it, the reader is treated to a masterful geopolitical survey of Europe at the outbreak of the war in 1740 .

Having set the story in this broad context, the book concentrates on French affairs and recounts them in the vein of satirical Orientalism made popular by Montesquieu's Lettres persanes. Every minister, every mistress of Louis XV receives an elaborate description, both physical and moral. Here is how the king himself appears:

Cha-Sephi [we are in Persia] at the age of sixteen to seventeen was handsome with a favorable form; he had a perfectly well-shaped leg, a noble air, large eyes, a look more soft than proud, brown eyebrows and a delicate temperament. ... His education having been neglected, his mind remained under-furnished. He had a gentle and timid character and an invincible distaste for [public] affairs, which he could not bear even to have mentioned in his presence. He spent most of his time hunting ... and at first proved indifferent to women and food, [the pleasures] that he loved greatly in his later years. A good king, a good master, capable of friendship ... [ but] more feeble than great, too indifferent to glory, indolent, hating and fearing work, ungenerous, not unintelligent but seeing everything through the eyes of the Athematdou [first minister] Ismael-Beg [Fleury], on whom he was dependent, too dependent; in a word [he was] a prince lacking the soul that sets apart a true king. ${ }^{26}$

The description seems balanced, objective, well-informed; and it treats the reader to a sight that lay beyond most mortals' range of vision. The frisson provided by this inside view is difficult to appreciate today, when everyone sees heads of state every day in newspapers and on television. Few French people could form a clear picture of their king in the eighteenth century, even though his image appeared on 
coins and engravings. In order to imagine him, they needed help from descriptions like the one here, which provided delicious details about physical qualities such as the shape of his leg and then went on to reveal the basic traits of his character. All the other kings, queens, generals, ministers, and mistresses received similar portraits, always disguised with tantalizingly exotic names. They also appeared in alphabetical order under their pseudonyms in an enormous appendix, forty-eight pages long in some editions, which provided biographical sketches and references to the passages where they appeared. The book could therefore be consulted as a Who's Who, and the reader could jump about in the text, following the fate of all the leading actors on the European stage.

Although some might use the Mémoires secrets as a reference work, most readers would be expected to proceed through the narrative from beginning to end, guessing along the way at the true identities of the Orientals whose names always appeared in italics. But the cast of characters was enormous, and it covered all the principal actors in European affairs. So the guessing game- a biographical puzzle imposed on a geographical puzzle - probably stretched the capacities of the bestinformed, and no reader could keep things straight without a key. Many copies contained keys, either handwritten or printed, but the keys varied and sometimes even contradicted one another. I have examined six of them in the Bibliothèque nationale de France and the Bibliothèque de l'Arsenal. ${ }^{27}$ One contains 168 names, and its text has a dozen others written in the margins in what appears to be an eighteenth-century hand. Another printed key runs to 208 names, including 25 added by hand. The online Catalogue collectif de France lists copies with keys and manuscript annotations in many provincial libraries. All the evidence suggests that a large number of French readers puzzled their way through the text, following the same clues to the same answers, except in the most obscure areas where the identifications remained ambiguous. The narrative is so rich and complex that it drew them deeper and deeper into the guessing game - and the game, at bottom, turned into an attempt to decipher the secrets at the heart of French politics. The ultimate secret, "le secret du roi," lay inside the innermost chambers of Versailles, the "petits apartements," where the king pursued his private life and the fate of France was determined by the rise and fall of ministers linked to the coming and going of mistresses. The message was the same as that of Tanastès. It made the monarchy look rotten-not, however, by exploiting scandal in the manner of a chronique scandaleuse, although it did make room for sex with the de Nesle sisters, but rather by providing a survey of domestic and foreign affairs. For all its exoticism, it reads like serious history, the generic opposite of Mlle Bonafon's fairy tale.

The next roman à clef belonged to literature. Les Amours de Zeokinizul, roi des Kofirans, probably written by Crébillon fils or by Angliviel de La Beaumelle, appeared two years after the Mémoires secrets pour servir à l'histoire de Perse but covered the same story, minus the geopolitics. This time the setting was Africa and the 
guessing game was a matter of decoding anagrams, most of them quite easy: the Kofirans are the Français; Zeokinizul, Louis Quinze; Zokitarezoul, Louis Quatorze; Jeflur, Fleury; and so on. Some of the anagrams are comic: Vorompdap = Pompadour. A few are difficult: omerisserufs = sous-fermiers (subordinate tax collectors.) And the difficulties increase as the reader penetrates deeper into the story. The kam de Kelirieu is the duc de Richelieu, as the context makes clear. But the kam de Lundamberk? (The duc de Cumberland.) Nasica? (Mlle de Jansac.) The archduke of Tuscany appears in one place under the name of Katenos and in another as Sicidem. One could imagine Parisian wits treating the text as a party game, reading it aloud and laughing or applauding with each identification of a personage.

In order to do so, they would have had to be armed with a key. But which key? The four editions published between 1747 and 1770 in the Bibliothèque nationale de France (at least eight editions appeared before 1789, and Firestone Library in Princeton has a copy that may come from a manuscript "edition") contain different keys: one gives the solution to forty-four anagrams, another to fifty-eight, a third to sixty-five; and a fourth has no key at all. ${ }^{28}$ They disagree in places, and eighteenthcentury readers evidently disagreed with them, because marginal notes provide additions and corrections to the keys bound with the texts. But there is no mistaking the identity of the principal characters nor the direction of the story line.

It runs through the main events of the 1740s, pausing occasionally for patches of dialogue and for winks and nudges aimed at readers attuned to hints about sex in high places. It is all rather light-hearted, funny, bawdy, fast-paced, and told with considerable skill in the manner of Crébillon's racy novels, Le Sofa and L'Ecumoire. (Krinelbol, the name of the putative author which appears on the title page, is an anagram of Crébillon, but it could have served as camouflage for someone else.) Instead of high politics, we get low intrigue, most of it directed by the clergy and turning on the king's libido. Cardinal Fleury persuades the queen's confessor to threaten her with damnation if she continues to have sex with the king; then he assigns the duc de Richelieu to arrange a tryst between the king and Mme de Mailly, who is old and ugly but easily manipulated. After a great deal of fumbling, recounted in comic dialogue, the king succumbs and never turns back: he sleeps his way through the de Nesle sisters, survives the crisis at Metz, and takes up with Pompadour, as recounted in Tanastès. But this time the story has a moral closer to the favorite themes of Voltaire and Montesquieu. The kingdom of the Kofirans has succumbed to the evil influence of imams, fakirs, and mullahs; and the king, stupid, ineffectual, and a victim of his passions, has turned into an oriental despot: "The government, once monarchical, became purely despotic." 29

The narrative skill and anticlerical bite of Les Amours de Zeokinizul makes the last roman à clef, Voyage d'Amatonthe (1750) look feeble in comparison. This time, however, we know a great deal about the author, Clément Ignace de Rességuier, a young ensign in the gardes françaises, because the police captured him and interro- 
gated him in the Bastille. When pressed to explain why he had the audacity to write such an outspoken satire, he replied that he had fallen into a conversation with a friend. They talked about his miserable circumstances compared with the undeserved fortune of the court grandees: "He said the only way to take vengeance was to laugh inwardly at the grandees; his imagination took fire and gave birth to that extravagance." ${ }^{30}$ As in the case of Mlle Bonafon, loose talk led to writing. But unlike her, Rességuier did not defend himself by arguing that he had merely published what was already circulating in the form of "public noises." On the contrary, he embraced his guilt: "I have written the most criminal work that can come from the hand of man. I certainly deserve to die; far from fleeing death, I demand it." ${ }^{31}$

What was so horrendous about the book? To the modern reader it is an insipid love story embedded in a travelogue. The narrator wanders through Amatonthe, an island kingdom off the coast of Greece, describing the dignitaries that he encounters in its court. They are all devoured by ambition, avarice, and lust; and all are equally incompetent. That, of course, is what made the book so criminal in the eyes of the police - and of Rességuier, as well. He confessed that he had been moved by "the mad desire to trace portraits. .. . I confess that they are applied to circumstances in a way that make them criminal." 32 In fact, there is nothing more to the novel. It is a series of satirical portraits strung together by an inconsequential plot. But French writers had often used sketches of supposedly fictitious characters as a way to skewer grandees, and state officials, especially censors, dreaded the possibility that "portraits" might appear in print. The term, a virtual synonym for "applications," represented the danger of damaging reputations, something that could destroy the career of a courtier and of the officials who had failed to protect him.

The police therefore scoured Voyage d'Amatonthe for every offense that might be hidden in the text. Rességuier's dossier in the archives of the Bastille shows them at work, decoding furiously in order to uncover clues. The most outrageous analogies were the easiest to spot. Thus three of the wickedest malefactors: Amon (the maréchal de Belle-Isle), Ezon (the comte d'Argenson), and Sinon (the cardinal de Tencin.) The duc de Richelieu played the role of the principal villain (Adrante), and Mme de Pompadour seconded him as Ermise. But could Crysippe be identified with Machault? Ariste with Maurepas? And Phidamas with the maréchal de Saxe? Who were Cydalise, Epaminondas, Zélide, and Iphis? The brain-teasers tormented the police, or so it seems from some notes that they scribbled in the margin of a confiscated copy. "The maréchal de Richelieu" appeared triumphantly next to a description of Adrante, but a sketch of Elphise provoked perplexity: "it seems that this satirical portrait is aimed at the daughter of a minister of Louis XV." ${ }^{33}$ In fact, the police did a remarkable job of textual exegesis. After confiscating Rességuier's papers - a mass of bad poems, short stories, and letters stashed in the furnished room that he rented from a wigmaker in the rue Serpente - they studied every scrap and then collated the printed version of Voyage d'Amatonthe against the manuscript. They noted all the passages that Rességuier had deleted from the manuscript, 
copied them on slips of paper, and pasted the slips on the appropriate pages of the printed copy. The result was a palimpsest that would have brought joy to the heart of a modern textual critic; but what it proved to the police is impossible to say, because they left it in Rességuier's dossier, a heap of disordered documents, without a covering memorandum that explained their conclusions.

Although he did not reveal the sources of his portraits, Rességuier made his own conclusion clear in the text itself:

Can it then be that thrones, those sacred sanctuaries of justice and authority, are surrounded by nothing but crime? I have seen important positions filled by men who are incapable of coping with them. They abandon their responsibilities in order to pursue pleasure. Accustomed to a soft life, they lack the strength to undertake anything difficult. Like sybarites, they care only for indolence. ${ }^{34}$

Rességuier's roman à clef provided the kind of keyhole peeping that made the genre so attractive to eighteenth-century readers. When he put his eye to the keyholes in Versailles, he saw nothing but incompetence and depravity; and when he wrote up what he had seen, his portraits made the government look like a gallery of rogues.

I hope I have not lost my argument in details about who stood for whom in the obscure political literature of the $1740 \mathrm{~s}$; so let me try to pull its threads together. Taken as a whole, the romans à clef worked court gossip and "public noises" into a vivid account of contemporary history. They combined two ingredients: portraits, which exposed the dramatis personae at the heart of great events, and plot, which showed the direction that the events had taken and were likely to take in the future. This combination may not look impressive to the modern reader, who finds biographies of contemporaries and analyses of current events in every bookstore. But both genres were illegal in eighteenth-century France. Readers could not find uncensored descriptions of the main characters and tendencies of contemporary history, except in two places: gossip and forbidden books. Mlle Bonafon brought the two together in 1745. She did not break the story of Louis XV's private life, because it could be picked up easily from the loose talk of courtiers and servants; but she organized it as a narrative and brought it out in print. Her version fed the others, and they touched off further rounds of rumors, which found their way back into later books. The mutual reinforcement of oral and printed communication kept gathering force, despite the state's attempts at repression, until it swept everything before it in the flood of forbidden best-sellers in the 1770s and 1780s. Traces of the spoken word - bons mots, jokes, gossip, songs - show up everywhere in that prerevolutionary literature. But the process of condensing talk and print began in the cluster of books that appeared between 1745 and 1750 . Hence the importance of forgotten characters like Mlle Bonafon and Mme de Vieux-Maisons.

Their importance appears all the more impressive, if you examine the connec- 
tions between the narratives from the midcentury and the prerevolutionary periods. Consider La Vie privée de Louis $X V$, a very popular and very illegal biography of the king published in 1781. It provides a sweeping, four-volume survey of the entire reign, and it locates a critical turning point of the reign in the 1740s, when Louis tried and failed to rule as his own prime minister, turned his back on the queen, and fell under the spell of a series of mistresses, from the de Nesle sisters to Mme de Pompadour. Every detail in its account of this period comes from the books I have discussed. Entire passages are lifted from them, word for word, and the same passages can be found scattered throughout the other best-sellers of the prerevolutionary years.

If you read your way through all this literature, you find something more than an accumulation of anecdotes, more even than intertextuality: you can discern a master narrative, which linked all the events together in a general vision of the recent past. Thanks to Mlle Bonafon and her successors, the French had an overview of contemporary history. They could relate the present to the past in a way that helped them make sense of the crisis that occurred at the end of the 1780s. Having learned to read events by deciphering romans à clef, they had acquired a key to the understanding of current politics. It seems fateful in retrospect that their view of the political system should have owed so much to the fairy tale imagined by a chambermaid in 1745 and that it should have corresponded so badly to the actual character of the French state on the eve of 1789. That is my answer to the "so what" objection to research on gossip and forbidden books. It does not reveal what happened but what people thought had happened - what they really thought. The Rankean formula has not lost its pertinence, but it needs to be applied in the manner of Tarde - that is, in new ways to a new field: the history of the media and of public opinion.

\section{Appendix}

The following passage from Mémoires secrets pour servir à l'histoire de Perse (Amsterdam, 1745), 146-47, illustrates how the text operated simultaneously as a geographical and a political puzzle. The names to be deciphered appear in italics and are identified after the passage by an alphabetical list extracted from the key:

Scadeck, tel que nous venons de le représenter, avait, dit-on, formé un grand projet, dont il fit part à l'Athémadoulet. Il consistait non seulement à procurer la couronne du Mogol au Raja de Visapour, en gagnant quelques uns des principaux Rajas et en intimidant les autres, mais encore à porter un coup mortel à la maison de Delly, en lui enlevant ses plus beaux états, pour en faire un établissement à Cha-Baskan. . . . Il était nècessaire de faire passer dans les états de Visapour une armée de cent mille hommes, qui sous le nom de troupes auxiliaires du Raja et sous le prétexte de lui aider à faire valoir ses droits sur la succession de Cha-

Ressinc-Frola, s'emparerait de la principauté de Delly, du royaume de fénupar, et des plus belles provinces de Golconde ... ; qu'il fallait faire marcher une autre armée de quarante 
mille hommes au moins dans les états du Raja de Multan, pour les protéger, contenir ses voisins et pour être à portée d'entrer dans la principauté de Cabul, dont l'Empereur du Japon, qu'on savait être pour la maison de Delly, était Raja; et, surtout s'assurer du Roi de Zagathay, dont l'irruption récente dans la province de Bacar, était une puissante diversion toute faite, dont il était essentiel de profiter; que cependant l'Empereur de Chine attaquât conjointement avec le Roi de la Cochinchine son fils les états que la Reine de Golconde possédait au-delà du Gange; mais que de la promptitude dans l'exécution et la profusion de l'argent dépendait la réussite de cette affaire, qui ne pouvait pas durer plus de six mois, si on suivait exactement ce plan.

Excerpts from the key:

Athémadoulet: the first minister (Fleury)

Bacar: Silesia

Cha-Baskan: Charles Albert, Elector of Bavaria and Holy Roman Emperor as Charles VII

Cha-Ressing-Frola: Charles VI, Holy Roman Emperor

Chine: Spain

Cochinchine: Kingdom of Naples and Sicily

Delly: Archduchy of Austria

Gange (le pays au-delà du): Italy

Golconde: Kingdom of Hungary

Japon: Britain

Jénup: Kingdom of Bohemia

Jénupar: Prague

Mogol: Holy Roman Empire

Multan: Electorate of Cologne

Raja: Elector

Scadeck: the maréchal de Belle-Isle

Visapour: Bavaria

Zagathay: Prussia

\section{Notes}

1. The best historical repository of Mother Goose rhymes remains Iona and Peter Opie, eds., The Oxford Dictionary of Nursery Rhymes (London, 1975). See esp. 107, 144, 152, 264 , and 416.

2. The most notable exception is Arlette Farge, Dire et mal dire: l'opinion publique au XVIIIe siècle (Paris, 1992). For an excellent study of communication networks far removed from Paris, see C. A. Bayly, Empire and Information: Intelligence Gathering and Social Communication in India, 1780-1870 (Cambridge, 1999).

3. Robert Darnton, The Forbidden Best-Sellers of Pre-revolutionary France (New York, 1995). See esp. chap. 2 and the bibliographical details in the accompanying volume, Robert Darnton, The Corpus of Clandestine Literature in France, 1769-1789 (New York, 1995).

4. The following account is based on the dossier of Marie-Madeleine Bonafon in the Bibliothèque de l'Arsenal, ms. 11582. It is actually a box full of documents in considerable 
disorder, although the interrogations and police reports quoted later in this essay can easily be identified. Some of the documents, although not the most important, were published by François Ravaisson, Archives de la Bastille (Paris, 1883), 15:260-71. I have not been able to consult a study of the Bonafon affair by Maurice Boutry: "De la cour de Versailles aux Bernardines de Moulins (1745-1759)," in Curiosités bourbonnaises (1898); but I have profited from the excellent work of Lisa Jane Graham, If the King Only Knew: Seditious Speech in the Reign of Louis XV (Charlottesville, 2000), 56-95, and from references to the affair in Françoise Weil, L'Interdiction du roman et la librairie, 1728-1750 (Paris, 1986), 345-47, and Farge, Dire et mal dire, 165.

5. The following quotations come from the transcriptions of Mlle Bonafon's three interrogations: Bibliothèque de l'Arsenal, ms. 11582, fols. 55-57, 79-80, and 115-16. As indicated in the text earlier, I have summarized parts of the dialogue (those not set off by quotation marks), but I have kept close to the original, which, like all interrogations, was written in the past tense: "Asked ... "; "Answered that ...," etc. Unless otherwise noted, all translations are my own.

6. Gabriel Tarde's best-known work is Les Lois de l'imitation. Etude sociologique (Paris, 1890), but the book most relevant to the study of public opinion is L'Opinion et la foule (Paris, 1901), which has some affinities with Benedict Anderson, Imagined Communities: Reflections on the Origin and Spread of Nationalism, rev. ed. (London, 1991).

7. These remarks owe a good deal to private conversations with Elihu Katz, who surveyed the literature in this field in "Communication research since Lazarsfeld," Public Opinion Quarterly 50 (1987): 25-45. I would also like to record my debt to Robert Merton, who introduced me to communication theory in 1973. His Mass Persuasion (New York, 1946) remains one of the finest studies in this branch of sociology. For references to other pathbreaking works from the 1940s, see Paul Lazarsfeld and Frank Stanton, eds., Communication Research (New York, 1949).

8. The history of journalism under the Old Regime has been renewed and rewritten by Jean Sgard, Pierre Rétat, and others during the last twenty years. For information on the periodicals discussed here, see esp. the collective volumes edited by Jean Sgard: Dictionnaire des journaux, 1600-1789 (Oxford, 1991) and Dictionnaire des journalistes, 1600-1789 (Oxford, 1999).

9. Gazette d'Amsterdam, May 6, 1749, Bibliothèque de l'Arsenal, $4^{\circ} \mathrm{H} .8,929$. The publication dates of eighteenth-century journals usually are much later than the dates of the reports of events, which are written as letters from the places where they occur.

10. Gazette d'Utrecht, May 2, 1749, Bibliothèque de l'Arsenal, $4^{\circ} \mathrm{H} .8,931$. Gazette de France, May 3, 1749, Bibliothèque de l'Arsenal, $4^{\circ} \mathrm{H} .8,917$.

11. On nouvelles à la main, including the journal produced from the salon of Mme Doublet, see François Moureau, Répertoire des nouvelles à la main. Dictionnaire de la presse manuscrite clandestine XVIe-XVIIIe siecle (Oxford, 1999). The most recent of the many studies of the Doublet group and its Mémoires secrets pour servir à l'histoire de la république des lettres en France is Jeremy D. Popkin and Bernadette Fort, eds., The Mémoires secrets and the Culture of Publicity in Eighteenth-Century France (Oxford, 1998).

12. Bibliothèque nationale de France, ms. fr. 13709, fol. 32.

13. Louis Sebastien Mercier, Les Entretiens du Palais-Royal (Utrecht, 1786), 1:43. In this work and its sequel, Les Entretiens du Jardin des Thuileries de Paris (Paris, 1788), Mercier's descriptions of casual conversation frequently illustrate connections between reading (more often of pamphlets than of journals) and talking.

14. Bibliothèque de l'Arsenal, ms. 12725, "Etats des papiers de la Bastille."

15. Bibliothèque de l'Arsenal, ms. 686, "Journaux de Mouhy," March 31, 1740. 
16. Bibliothèque de l'Arsenal, ms. 12725, entry for August 24, 1745.

17. Bibliothèque de l'Arsenal, ms. 11582, fol. 20.

18. Ibid.

19. This summary is based on the copy in the Bibliothèque de l'Arsenal, $8^{\circ}$ B. L. 19489 , which includes a manuscript key to the names of the personages hidden behind the characters in the fairy tale. The book's character as a roman à clef was indicated clearly by its title: Tanastès. Conte allégorique par Mlle de xxx (The Hague, 1745).

20. Bibliothèque de l'Arsenal, ms. 7067, "Clés de romans à clefs." Some of the keys go back to the works of Rabelais.

21. Bibliothèque de l'Arsenal, ms. 7067, fol. 24.

22. For a sober account of these events, see Michel Antoine, Louis $X V$ (Paris, 1989), chaps. 8-10.

23. Tanastès, 80 .

24. The book is attributed to Antoine Pecquet in A.-A. Barbier's Dictionnaire des anonymes, and I think the attribution is confirmed by a passage in the text, which concerns a dispute within the ministry of foreign affairs that damaged Pecquet's career: Mémoires secrets pour servir à l'histoire de Perse (Amsterdam, 1745), 94-96. The same passage can be found with Pecquet's name included in Vie privée de Louis $X V$, ou principaux événements, particularités et anecdotes de son règne (London, 1781), 2:38-41.

25. Bibliothèque nationale de France, ms. nouvelles acquisitions françaises 10783, fol. 146 .

26. Mémoires secrets pour servir à l'histoire de Perse, 30-31.

27. Bibliothèque nationale de France, $8^{\circ} \mathrm{Lb} 38.45 \mathrm{~A}-\mathrm{E}$ and Bibliothèque de l'Arsenal, $8^{\circ} \mathrm{H} .8505$.

28. The copies in the Bibliothèque nationale de France are bound together under the call number $8^{\circ} \mathrm{Lb} 38.554$. A-D.

29. Les Amours de Zéokinizul roi des Kofirans. Ouvrage traduit de l'arabe du voyageur Krinelbol (Amsterdam, 1747), 17. This denunciation of despotism accompanies an argument favoring the power of the parlements and the provincial estates.

30. Bibliothèque de l'Arsenal, ms. 11733, fol. 15, interrogation of Clément Ignace de Rességuier. The dossier of this affair contains many letters and police reports, a manuscript draft of Voyage d'Amatonthe, which is much more violent than the printed version of the book, and a copy of the printed version, heavily annotated by the police.

31. Bibliothèque de l'Arsenal, ms. 11733, letter from Rességuier to, apparently, the governor of the Bastille, Dec. 16, 1750.

32. Ibid.

33. Voyage d'Amatonthe (London, 1750), 6. The margin notes are in the copy with Rességuier's dossier, Bibliothèque de l'Arsenal, ms. 11733.

34. Ibid., 34. 